\title{
Para Politikası Tercihleri İle İşsizlik Oranları Arasındaki illişki
}

\section{The Relation between Monetary Policy Preferences and Unemployment Rates}

\author{
Emrah İsmail ÇEVIK', \\ Durmuş Çağrı YILDIRIM²
}

\begin{abstract}
ÖZET
Bu çalışmada TCMB tarafından uygulanan para politikası tercihleri ile işsizlik oranları arasındaki ilişki 1999 ile 2014 dönemi için analiz edilmektedir. Çalışmamızda para politikası kuralı olarak Taylor kuralı dikkate alınmış ve Markov rejim değişim modeli kullanarak aktif ve pasif para politikasının uygulandığı dönemler belirlenmiştir. Ardından, eğilim skoru eşleştirme yöntemi kullanarak, para politikasının aktif olarak uygulandığı dönemlerde işsizlik oranlarının daha yüksek olduğu sonucuna varılmıştır. Bu sonuçlar, TCMB'nin ekonomik istikrarı sağlaması açısından para politikası tercihlerinde enflasyon oranının yanında çıktı açı̆ııı dikkate alan politika karmasını tercih etmesinin uygun olacağı anlamına gelmektedir.
\end{abstract}

Anahtar Kelimeler: Para Politikası, Taylor Kuralı, Işsizlik Oranları, Markov rejim değişim modeli.

\section{GíRiş}

Küresel krizle beraber para politikasının etkinliği ve merkez bankası uygulamalarının küresel kriz ile mücadeledeki rolleri yaygın şekilde tartışma konusu haline gelmiştir. Bir yandan kurala dayalı politika uygulamalarının sıkı şekilde takip edilmemesinin, iktisadi temellerden kopuşa ve dolayısıyla balonlara neden olduğu görüşleri diğer yandan kurala dayalı politikaların reel ekonomiyi yeterince açıklayamadığı ve istikrarsızlaştırıcı politika önerileri sunduğuna ilişkin görüşler yer almaktadır.

Merkez bankaları ekonomik istikrar ve hedeflere ulaşmak için para politikası uygulamalarına gitmektedirler. Literatürde istikrar sağlamaya ve hedeflere ulaşmaya yönelik olarak uygulamaya konulan politikalar, bir yandan merkez bankası takdirine bağlı olabilirken bir yandan kurallar çerçevesinde uygu-

\begin{abstract}
The aim of this study is to examine the relation between CBRT's monetary policy preferences and unemployment rates for the periods of 1999-2014. We consider Taylor rule as a monetary policy rule and employ Markov regime-switching model to determine the periods of "active" and "passive" monetary policy regimes. After that, we find higher unemployment rates in the periods of active monetary policy regime by using propensity score matching. These findings suggest that the CBRT should conduct monetary policy mix where it is considered not only inflation rates but also output gap to provide economic stability.
\end{abstract}

Keywords: Monetary Policy, Taylor Rule, Unemployment Rates, Markov Regime Switching Model.

lanabilmektedir. Bu noktada karşımıza çıkan önemli bir konu hangi politikanın daha etkin şekilde merkez bankalarına hizmet ettiğidir. Politikaların etkinliğinin ölçülmesinde ekonominin içinde bulunduğu şartlar, özel durumlar, konjonktürel gelişmeler, dönem gibi birçok değişken etkili olmaktadır. Bu bağlamda aktif (takdir yetkisine dayalı) ve kurala dayalı politikaların karşılaştırılmasında, uygulandığı dönem ve ekonomik şartlar gibi faktörlerin değerlendirilmeye alınması gerekmektedir.

Katı kurallara dayanan para politikası stratejileri, ülkelerin yaşadıkları içsel ve dışsal şoklar karşısında sürdürülebilirlikten uzaklaşmaktadır. Bu bağlamda katı kurallara dayalı para politikası uygulamalarına alternatif politika arayışları ile taahhüt içeren politikaların gerekliliği, esnek kuralların oluşmasına zemin hazırlamıştır. Bu bağlamda ön taahhüt, politikanın 
uygulanmasının sağlanması yanında güvenilirlik ve kredibiliteye katkı sağlamaktadır. Kuraldan sapılması ise hesap verme mekanizmasının işletilmesini gerektirmektedir (Yay, 2006). Esnek kurallara karşı aktif para politikasını savunanlar, politika yapıcıların kural çerçevesinde tanımlanmış değişkenler yerine birçok diğer değişkenleri de göz önüne almaları gerekliliğini ön plana çıkarmaktadırlar. Böylece şoklara karşı daha doğru ve hızlı şekilde tepki verilmesi mümkün olacaktır.

Doğru şekilde dizayn edilmiş aktif politika uygulamalarının makroekonomik dengesizlikleri giderdikleri ve işsizlik ve enflasyon rakamlarında ortaya çıkan konjonktür dalgalarını azalttıkları yaygın şekilde kabul edilmektedir. Böylece para politikası uygulamaları, bir bütün olarak ekonomik istikrara ve refaha katkı sağlayabilmektedir (Orphanides, 2007). Negatif bir şok karşısında politika yapıcının ters yönde politika uygulamasına gitmesi şeklinde tanımlanan politikalara, rüzgara karşı direnme stratejisi denmektedir. Bu strateji ile negatif şok karşısında faiz oranlarının düşürülmesi, ekonominin denge düzeyine daha hızı dönmesini sağlayacaktır (Agur \& Demertzis, 2013).

Aktif para politikası stratejilerinin ekonomik istikrara katkı yaptığı görüşü yanında istikrarsızlık yarattığına dair görüşler de mevcuttur. Aktif para politikası stratejilerine karşı dört argüman mevcuttur. Bunlar para politikası uygulamalarının ekonomi üzerindeki etkilerinin değişken bir süreyi kapsaması ve gecikmeli bir etkinin söz konusu olması, zaman tutarsızlık sorunsalı, Phillips eğrisi analizinin geçersizliği ve enflasyonun maliyetleri olarak karşımıza çıkmaktadır (Erdoğan S. , 2013).

Monetarist ekol para politikası stratejilerinin ekonomiyi gecikmeli olarak etkilediğini ve para politikası uygulamalarının nominal hasılayı 6-9 aylık süreçte enflasyon seviyesini ise 12-18 aylık süreçte etkilediğini vurgulanmaktadır. İkinci olarak petrol krizinde Phillips eğrisi analizinin çöküşü ile enflasyon ve işsizlik arasında bir değiş tokuş ilişkisinin var olmadığının gösterilmesi aktif politika uygulamalarının gereksizliğini göstermektedir. Zaman tutarsızlığı sorunu ile merkez bankaları kredibilitelerini kaybetmekte ve enflasyonla mücadele politikalarının maliyetleri yükselmektedir. Aktif politikalar yerine kurala dayalı politikaların takip edilmesi zaman tutarsızlığı sorununu ortadan kaldırırken diğer yandan merkez bankasının kredibilitesine de katkı sağlayacaktır. Enflasyonun ekonomi üzerinde ciddi maliyetleri mevcuttur. Bu maliyetlerin ortadan kaldırılması için hedefleme stratejilerinin (Döviz kuru çıpası, parasal hedefleme, enflasyon hedeflemesi) takip edilmesi önerilmektedir.

Hedefleme stratejisi uygulayan ülkelerin deneyimleri incelendiğinde fiyat istikrarının sağlanması için döviz kuru hedeflemesi ve parasal hedeflemesi stratejilerinin kalıcı çözüm sunmadıkları görülmüştür. Merkez bankalarının fiyat istikrarı için nominal çıpa arayışları enflasyon hedeflemesi stratejisinin ortaya çıkmasına zemin hazırlamıştır. Yeniz Zelanda ile 1989 yılında başarılı şekilde uygulanmaya başlayan enflasyon hedeflemesi stratejisini günümüzde birçok gelişmiş ve gelişmekte olan ülke takip etmektedir (Erdoğan, Yıldırım, \& Güneş, 2010). Birçok politika yapıcı ve ekonomist merkez bankalarının, belirli bir enflasyon seviyesi hedefini takip etmesi gerektiğine vurgu yapmasına rağmen diğer bir grup enflasyon hedeflemesi stratejisinin Taylor kuralı vasıtası ile uygulanması gerektiğini önermektedir (Ball L. , 1999).

Bu çalışmada alternatif bir para politikası stratejisi olarak enflasyon hedeflemesi stratejisi altında merkez bankası para politikasının tanımlanması için bir araç olarak Taylor kuralının etkinliği, Markov rejim değişim modeli yardımı ile Türkiye özelinde araştırımaya çalışılmaktadır. Bu bağlamda TCMB tarafından tercih edilen para politikası rejimleri belirlenecek ve para politikası tercihlerinin işsizlik oranları üzerindeki etkisi eğilim skoru eşleştirme tekniği kullanılarak araştırılacaktır. İlk bölümde Taylor kuralı ele alındıktan sonra ikinci bölümde literatür taraması yer verilecektir. Üçüncü bölümde ise ekonometrik model ve ampirik analize yer verildikten sonra elde edilen bulgular tartışılmaktadır.

\section{Taylor Kuralı}

Taylor kuralı, Standford Üniversitesi'nden John B. Taylor tarafından geliştirilen bir kurala bağlı para politikası stratejisidir. Bu strateji, merkez bankasının kısa dönemli istikrar hedefi ile uzun dönemli fiyat istikrarı hedefine ulaşmak için para politikası aracı olarak faizi nasıl kullanması gerektiğine dair bir öneri sunmaktadır. Taylor kuralı, merkez bankasının uyguladığı para politikasını hem tanımlayan hem de öngören bir stratejidir.

Taylor (1993), 1980-1990 yılları için ABD ekonomisinde politika faiz oranlarını inceleyerek basit bir reaksiyon fonksiyonu oluşturmuştur. Bu fonksiyon ile temel makroekonomik değişkenlerin (enflasyon ve çıktı açığı) hareketlerine karşı bir para politikası 
enstrümanının (kısa vadeli faiz oranı) tepkisini göstermeye çalışmıştır.

Taylor ile birlikte ABD için 1980-1990 dönemini kapsayan birçok para politikası kuralı mevcuttur. Tablo 1'de bunlar görülmektedir.

Tablo 1'deki kurallar incelendiğinde Taylor kuralını takip ettikleri ve benzerlik taşıdıkları görülmektedir. Çalışmamız açısından önemli olan konu enflasyon hedeflemesi stratejisi altında Taylor kuralının etkinliğinin incelenmesidir.

Taylor (1993), politika reaksiyon fonksiyonu geliştirerek Merkez Bankalarının faiz oranı ayarlaması için basit bir araç kural ortaya koymuştur.

$i_{t}=r^{*}+\pi^{*}+\beta\left(\pi_{t}-\pi^{*}\right)+\gamma\left(y_{t}-y^{*}\right)$

Denklem (1)'de $i_{t}$ : politika (kısa vadeli) faiz oranını $r^{*}$ : reel faiz oranı (uzun vadeli faiz oranı),: gerçekleşen enflasyon oranını, $\pi^{*}$ : hedeflenen enflasyon oranını, $y_{i}$ : gerçekleşen hasıla seviyesini ve $y^{*}$ : potansiyel hasıla seviyesini ifade etmektedir. Denklemde $\beta, \gamma>0$ şeklindedir. Uzun dönemli ortalama faiz oranı, reel faiz oranına yakınsayacağından eşit kabul edilmektedir. Bu formüle göre gerçekleşen enflasyon hedeflenen enflasyondan saptığında ve hasıla, potansiyel seviyesinden saptığında politika faiz oranı 'nin uzun dönemli seviyesinin altında kalması ya da aşması gerekecektir.

Diğer bir ifade ile Taylor kuralı politika faiz oranını enflasyon ve çıktı açığına bağlamaktadır. Böylece enflasyon oranı hedef seviyesini aştığında ya da üretim potansiyel hasıla oranını aştığında faiz oranı artarak ekonomiyi denge seviyesine döndürmektedir.

Taylor kuralı için önemli bir ayrım ise ileriye ve geriye dönük reaksiyon fonksiyonlarından ortaya çıkmaktadır. Taylor (1993) reaksiyon fonksiyonunda, beklenen enflasyon oranının temsili için gerçekleşmiş enflasyon oranlarını kullanarak geriye dönük (backward looking) bir fonksiyon oluşturmuştur Clarida, vd. (1998) ileriye dönük bir reaksiyon fonksiyonu oluşturmuşlardır. İleriye dönük fonksiyon Denklem (2)'de görülmektedir.

Taylor kuralının basit ile ileriye dönük reaksiyon fonksiyonu arasındaki temel farklılık gelecek değerlerin fonksiyona dahil edilmesidir (Ardor \& Varlık, 2014). Diğer bir ifade ile fonksiyondaki değişkenlerin gelecek değerleri cari dönemde belirlenmektedir. Denklem (2)'de $\bar{r}$ uzun dönemli denge faiz oranı, $\pi_{(t+k)}, t$ ve $t+k$ dönemleri arasında enflasyon oranıdır. $y_{t+p} t$ ve $t+p$ dönemleri arasında reel hasıla oranı, $y_{t}^{*}$ potansiyel hasıla seviyesidir. Potansiyel hasıla seviyesinde ücret ve fiyatların tam esnek olduğu varsayılmaktadır. Ayrıca $E$, beklenen değer operatörüdür ve $\Omega_{t}$ ise politika oranının belirlendiği sırada merkez bankasının mevcut bilgisini göstermektedir. Merkez bankası büyük ihtimalle politika oranını seçerken çıktı ve fiyatlar genel seviyesinin cari değeri hakkında tam bilgiye sahip değildir. Clarida vd (1998) bu olasığı göz önüne alarak Denklem (3)'ü oluşturmuşlardır. Denklem, ex-ante örtük reel faiz oranı hedefi için yol göstericidir, $r r_{t}=r_{t}-E\left[\pi_{t+k} \mid \Omega_{t}\right]$.

Denklem (3)'de $r r$, uzun dönemli denge reel faiz oranıdır. Modelde reel faktörlerin $r r^{\prime}$ yi belirlediği öngörülmektedir. Denklem (3)'e göre hedef politika oranı, beklenen enflasyon ve çıktının nispi hedeflerinden sapmalarına karşı doğal orana göre belirlenmektedir. Burada $\beta$ parametresi önem arz etmektedir. Bu parametrenin 1'den büyük olması durumunda reel hedef oranı, hasılanın yanında enflasyonu istikrarlandırmak için ayarlanmaktadır $(\gamma>0$ ). 1'den küçük olduğunda politika oranı, enflasyondaki değişimleri bağdaştırmak için hareket etmektedir.

$$
\begin{aligned}
& i_{t}=\bar{r}+\pi^{*}+\beta\left(E\left[\pi_{(t+k)} \mid \Omega_{t}\right]-\pi^{*}\right)+\gamma\left(E\left[y_{(t+p)} \mid \Omega_{t}\right]-y_{t}^{*}\right) \\
& r r_{t}^{*}=\overline{r r}+(\beta-1)\left(E\left[\pi_{(t+k)} \mid \Omega_{t}\right]-\pi^{*}\right)+\gamma\left(E\left[y_{(t+p)} \mid \Omega_{t}\right]-y_{t}^{*}\right)
\end{aligned}
$$

Tablo 1: ABD için 1980-1990 döneminde önerilen politika kuralları

\begin{tabular}{|l|l|l|}
\hline 1 & Taylor (1993) & $i_{t}=r^{*}+\pi^{*}+0.5\left(\pi_{t}-\pi^{*}\right)+0.5\left(y_{t}-y_{N}\right)$ \\
\hline 2 & (Orphanides, 1997) & $i_{t}=0.66 i_{t-1}+0.34\left(1.8+1.64 E_{t} \pi_{t+4}+0.97 E_{t} y_{t+4}\right)$ \\
\hline 3 & (Clarida, Gali, \& Gertler, 2000) & $i_{t}=0.79 i_{t-1}+0.21\left(r^{*}-4.12+2.15 E_{t} \pi_{t+1}+0.93 E_{t} y_{t+1}\right)$ \\
\hline 4 & (Ball \&Tchaidze, 2002) & $i_{t}=1.47+1.54 \pi_{t}-1.67\left(u_{t}-u_{t}^{*}\right)$ \\
\hline 5 & (Orphanides \& Williams, 2003) & $i_{t}=0.72 i_{t-1}+0.28\left(r^{*}+1.26 \pi_{t}-1.83\left(u_{t}-u_{t}^{*}\right)-2.39\left(u_{t}-u_{t-1}\right)\right.$ \\
\hline
\end{tabular}


Taylor kuralının etkin şekilde kullanılması için karşımıza üç önemli konu çıkmaktadır. Bunlar hasıla açığının ölçümü, merkez bankasının bilgi sorunu ve yapısal değişimin hesaplanmasıdır (Chen \& Huo, 2009). Illk olarak hasıla açığının ölçülmesi, potansiyel hasılanın doğru ölçülmesine bağlıdır. Burada kullanılabilecek yöntemler olarak Kalman filtresi, HP filtresi, doğrusal zaman trendi yöntemi veya ikinci derece zaman trendi yöntemi karşımıza çıkmaktadır. Diğer taraftan Okun yasasına göre işsizlik ve hasıla açığı arasındaki yakın ilişkiden ötürü işsizlik, hasıla açığı için bir vekil değişken olarak kullanılabilmektedir (Orphanides, 2002).

Bir diğer konu ise Denklem (1)'deki $\beta$ ve $\gamma$ tepki katsayılarının doğru tahminin güç olmasından kaynaklanmaktadır. Merkez bankasının politika faiz oranlarını belirlerken cari dönem ve gelecek dönem hasıla açığı ve enflasyonun güvenilir tahminine ihtiyaç duymaktadır. Merkez bankası faiz politikasını belirlediği zaman güvenilir ön değerlendirme ve tahminler mevcut değildir. Ancak önceki dönem verilerin kullanılması politika tanımlanmasını hatalı kılabilmektedir (Orphanides, 1997, 2002). Bu sorundan kaçınmak için bir yöntem olarak Genelleştirilmiş Momentler Metodu (Generalized Methods of Moments-GMM) kullanılabilmektedir (Clarida, Gali, \& Gertler, 1998). Ayrıca Kim and Nelson (2006)'da geçmiş verilerle politika üretilmesini sağlayan geliştirilmiş Heckman-tipi iki aşamalı bir yöntem geliştirmişlerdir (Kim \& Nelson, 2006).

Diğer bir sorun ise yapısal değişim olarak karşımıza çıkmaktadır. Farklı dönemlerde reaksiyon fonksiyonu farklı şekilde düşünülmektedir. Yapısal değişimin ölçülmesi için Chow testi, zamanla değişen parametre modeli (the time-varying parameter model, TVP) ve Markov rejim değişim modeli (Markov regime switching model) kullanılabilmektedir Chen \& Huo, 2009).

Taylor Merkez Bankası tepki fonksiyonunu ekonometrik olarak tahmin etmemiş ve $\beta=0.5$ ve $\gamma=0.5$ olarak belirlemiş̧tir. Bu rakamları yerine koyduğumuzda Denklem (1) aşağıdaki gibi tekrar yazılabilir.

$i_{t}=r^{*}+\pi^{*}+0.5\left(\pi_{t}-\pi^{*}\right)+0.5\left(y_{t}-y^{*}\right)$

Taylor ABD için yaptığı araştırmasında enflasyon ve reel faiz oranlarını 2 olarak kabul etmiştir. Taylor'a göre enflasyon oranı, hedeflenen enflasyon oranını bir birim aştığında merkez bankası faiz oranlarını birden çok artırmalıdır. Böylece enflasyon, hedef seviyesine yaklaşır. Buna Taylor illkesi adı verilmektedir. Ancak bu durumda para politikası nominal çıpa işlevini kaybetmektedir. Enflasyon belli bir değerin altına sabitlenemez.

Türkiye ekonomisinde açık enflasyon hedeflemesine geçilen 2006 ve 2016 yılları arasında enflasyon gerçekleşmeleri ve politika faiz oranları Grafik 1'de görülmektedir.

Grafik 1'de incelendiğinde enflasyon gerçekleşmelerinin yüksek bir oynaklığa sahip olmadığı ve düşük bir seviyede dalgalandığı görülmektedir. Diğer yandan politika faiz oranları (bankalararası gecelik faiz oranları) özellikle 2009 döneminden itibaren hızla düştüğü görülmektedir. Bu durumun küresel kriz sonucunda ekonominin içerisinde bulunduğu daralmaya tepki olarak düşüşe geçtiği beklenmektedir. Diğer yandan ekonomik düzelme ile birlikte yeniden bir yükselme trendine geçtiği görülmektedir.

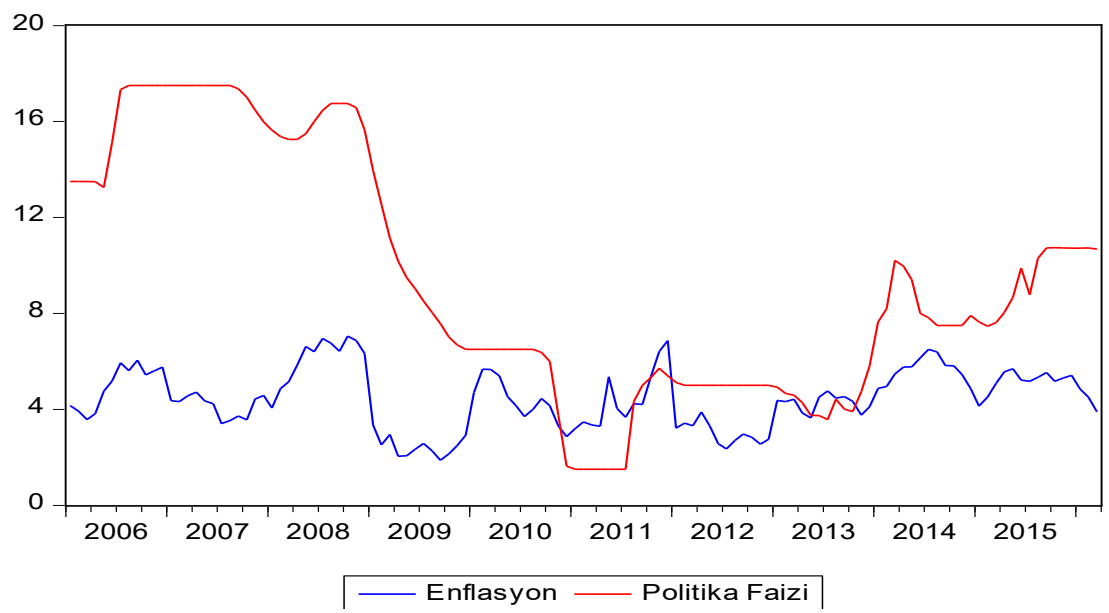

Grafik 1: Türkiye Ekonomisinde 2006-2016 döneminde gerçekleşen enflasyon ve politika faiz oranları. 


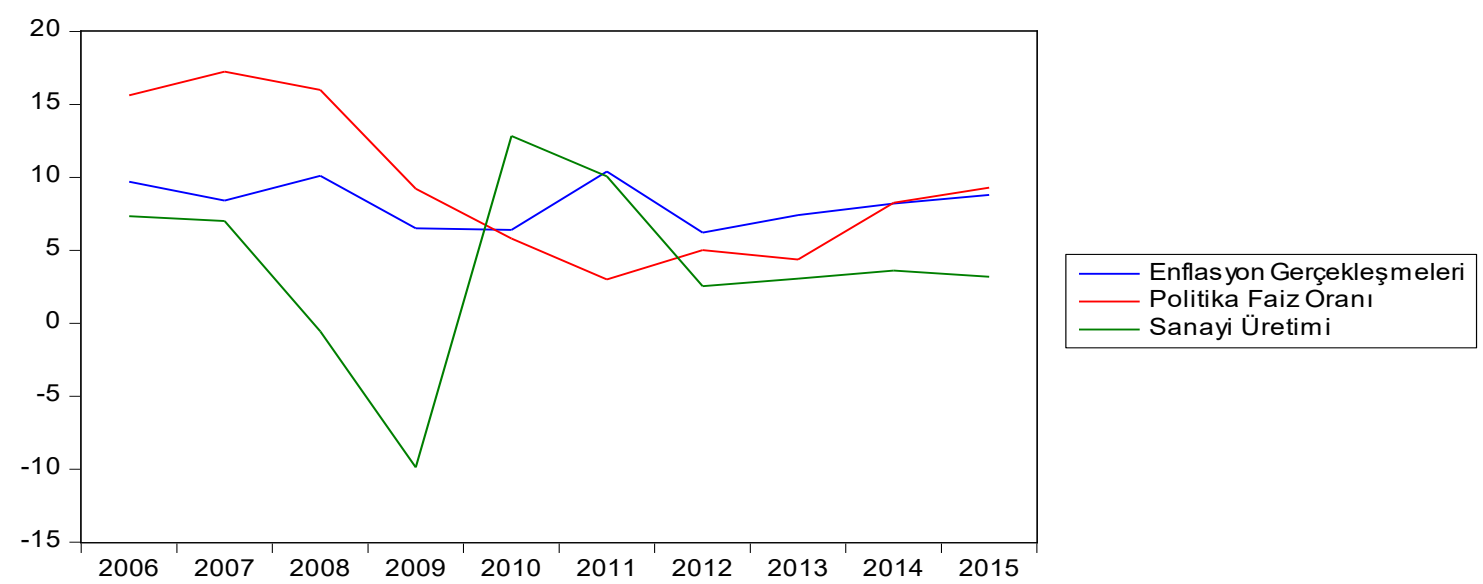

Grafik 2: Türkiye Ekonomisinde 2001-2016 döneminde politika faizi, enflasyon gerçekleşmeleri ve sanayi üretimi yıllık değişimi.

Grafik 2'de yıllık olarak politika faiz oranları, enflasyon gerçekleşmeleri ve sanayi üretim rakamları yer almaktadır. 2009 yılında sanayi üretimindeki düşüş ile birlikte politika faiz oranlarında da bir düşüşün gerçekleştiği görülmektedir. Diğer yandan faiz oranlarındaki düşüş ile 2010 yılından itibaren uyumlu bir şekilde enflasyon oranlarında yükselme eğilimi söz konusudur. Türkiye ekonomisi için politika faiz oranları ile enflasyon gerçekleşmeleri teori ile tutarlı bir görünüm sergilemektedir. Diğer bir ifade ile Fisher etkisinin geçerli olduğuna ilişkin bulgular mevcut değildir.

Fisher etkisinin geçerli olması durumunda nominal faiz oranları Merkez Bankası için enflasyonla mücadele de bir silah olma özelliğini kaybetmektedir. Diğer bir ifade ile Fisher etkisi Taylor kuralının karşısında yer almaktadır. Islam \& Ali (2012), ABD ekonomisi için 1970-2010 döneminde Fisher etkisi ve Taylor kuralının etkinliğine ilişkin bir analiz yapmışlardır. Analizlerinde 1957-2010 dönemi için ABD ekonomisinde kısa dönemde Taylor kuralı ve uzun dönemde Fisher etkisinin etkin olduğunu ortaya koymuşlardır. Çalışmamızda öncelikle ilgili literatürde yer alan çalışmalar irdelenecektir. Sonrasında ampirik analize yer verilecektir.

\section{Literatür Taraması}

Literatür başlığı altında ilk olarak çeşitli ülke deneyimlerine ilişkin çalışmalar ele alınmaktadır. Ardından Türkiye özelinde Taylor kuralını inceleyen çalışmalara yer verilmiştir.

\section{Farklı Ülke Örneklerini İnceleyen Çalışmalar}

Clarida, Gali \& Gertler (1998), çalışmalarında iki ülke grubu için analiz yapmışlardır: G3 (Almanya,
Japonya ve ABD) ile E3 (Ingiltere, Fransa ve Ittalya). 1979 yılından itibaren G3 merkez bankaları, bu dönemde ilgili ülkelerde para politikası başarısına yol açan örtük enflasyon hedeflenmesini takip etmişlerdir. Elde edilen sonuçlara göre bu merkez bankaları ileriye dönük kural takip etmektedirler Bu merkez bankaları, geçmiş enflasyon yerine beklenen enflasyona tepki göstermektedirler. E3 ülkeleri, Almanya para politikasından yoğun şekilde etkilenmektedirler. Dahası Bundesbank para politikası bir mihenk taşı olarak kullanılarak Avrupa Para Sistemi döneminde E3 ülkelerinin faiz oranlarının ulusal ekonomilerin gerektirdiğinden daha yüksek olduğunu göstermişlerdir. Sonuç olarak sabit döviz kuru yerine enflasyon hedeflemesinin daha üstün bir para politikası çıpası olduğuna ilişkin görüşü desteklemektedirler.

Bec, Salem, \& Collard (2002) çalışmalarında enflasyon ve çıktı hedeflerine göre merkez bankası tercihlerinin olası asimetrik doğasının ampirik bir araştırmasını önermektedirler. Tahminlerde ABD, Fransız ve Alman ekonomileri için aylık veriler kullanılmıştır. ABD için 1982:10-1998:8 dönemi, Fransa için 1983:7-1997:12 ve Almanya için 1982:1-1997:11 dönemi incelenmektedir. Çalışmada kullanılan eşik GMM (generalized method of moments) modeli sonuçlarına göre $A B D$, Fransa ve Almanya için para politikası reaksiyon fonksiyonlarının asimetrik olduğunu desteklemektedir. 82 yılından sonra FED ve Bundesbank, sadece genişleme dönemlerinde enflasyon ile ilgilenmektedirler. FED'in aksine Bundesbank genişleme dönemlerinde çıktı açığına daha fazla önem vermektedir. Fransa Merkez Bankası ise durgunluk döneminde enflasyon hedefine daha güçlü reaksiyon veren rekabetçi dezenflasyon politikası ile şekillenmektedir. 
Taylor \& Davradakis (2006) İngiltere için 1992:102003:1 döneminde Merkez Bankasının uyguladığı politika stratejisi için Taylor kuralının geçerli olduğunu ifade etmiştir. Martin ve Milas (2010) çalışmalarında Ingiltere için 1992:10-2007:4 döneminde Merkez Bankasının ileriye dönük Taylor Kuralını takip ettiğini ifade etmişlerdir.

Kuzin (2006) Almanya ekonomisinde 1978-1995 dönemi için çeyrek dönemlik verilerle enflasyon verilerini Markov rejim değişim parametresi ile geriye dönük bir Taylor kuralı tahmin etmiş̧ir. Çalışmanın ana bulgusu, Bundesbank'ın enflasyondaki gelişmelere ilişkin olarak reaksiyonlarının zamana göre sabit olmadığı ve parasal hedefleme döneminde bazı ani ve büyük değişimler gösterdiğidir. Bu durum, geriye dönük Taylor kuralında tahmin edilen enflasyon katsayısı değerinin genellikle 1'i aştığını ve böylece teorik para politikası modellerini ihlal ettiğini açıklamaktadır. Ayrıca sonuçlar, Bundesbank'ın enflasyonla mücadelede "fırsatçı bir yaklaşım" izlediğine ilişkin kanıtlar sunmaktadır.

(Sims \& Zha, 2006) çalışmalarında katsayılarda ve varyanslarda Markov dönüşümüne izin veren çok değişkenli bir model yardımıyla, ABD para politikasındaki rejim değişimlerini incelemişlerdir. Ancak, sabit katsayılı ve duruma bağlı varyanslı model uyum açısından en iyi performansı gösterdiği sonucuna varılmıştır.

Chen \& Huo (2009), çalışmalarında modifiye edilmiş bir Taylor kuralını Çin ekonomisi özelinde araştırmaktadırlar. Markov rejim değişim ve TVP modellerinin kullanıldığı çalışmada 1995-2008 döneminde iki yapısal değişim bulunmuştur. 1998'den önce net bir politika kuralı mevcut değildir ve modelden elde edilen katsayıların istatistiksel olarak anlamlı olmadığı görülmüştür. 1998-2002 döneminde beklenen enflasyon ve marjinal maliyet serilerinin katsayıları istatistiksel olarak anlamlı ve negatif değerler almaktadır. 2003-2008 döneminde tüm değişkenler anlamlı olarak bulunmuştur. 2002 döneminden sonra tüm gecikmeli değerler anlamlı çıkmaktadır. Yazarlar bu durumun Çin merkez bankasının ileriye dönük bir strateji izlemediğini gösterdiğini ifade etmektedirler.

Perruchoud (2009) çalışmasında 1975:1- 2007:12 döneminde İsviçre ekonomisi için Taylor kuralını Markov rejim değişim yöntemi ile analiz etmiştir. Çalışma sonucunda İsviçre para politikasını, yumuşak ve aktif bir rejim ile tanımlamışlardır. İsviçre para politikasının oluşturulmasında $\% 90$ oranda yumuşak rejim görülmüştür. Rejim 1, zaman zaman yumuşak rejimi kesintiye uğratan belirli olaylara karşı faiz oranlarının farklı reaksiyonlarını göstermektedir. Bu olayların birçoğu, döviz kurunun kendi trendinden anlık ve büyük sapmalarını ortadan kaldırmak için İsviçre Merkez Bankası'nın agresif politika reaksiyonundan ortaya çıkmaktadır.

Aizenman, Hutchison, \& Noy (2011) çalışmalarında yükselen piyasalar ve geçiş ekonomilerinde enflasyon hedeflemesinin doğasını araştırmışlardır. Bu bağlamda açık enflasyon hedeflemesi uygulayan 16 yüksek piyasa ekonomisinde 1989Q1-2006Q4 dönemi için panel data yöntemi ile yapılan analiz sonucunda faiz oranlarına enflasyonun tepki verdiğine dair anlamlı ve istikrarlı kanıtlara ulaşmışlardır. Diğer taraftan enflasyon hedeflemesi stratejisi takip etmeyen merkez bankalarının faiz oranları ayarlaması ile enflasyon oranları üzerinde daha düşük bir etkinliğe sahip oldukları görülmüştür. Enflasyon hedeflemesi uygulayan yükselen piyasa ülkelerinde para politikası, enflasyon ve döviz kurunun önemli belirleyiciler olduğu karma bir strateji takip etmektedir. Ayrıca reel döviz kurunun etkisi enflasyon hedeflemesi takip eden ülkelerde daha güçlü olduğuna dair kanıtlara ulaşılmıştır.

(Shi, 2012) çalışmasında, Taylor kuralı çerçevesinde Çin'in para politikasının ampirik bir analiz yapmak için reaksiyon fonksiyonunu kullanmıştır. Faiz oranının gerçek değeri ile kural değerini karşılaştırarak, Taylor kuralının Çin'in para politikasının duruşunun ölçülmesinde bir kriter sağlayabileceğini göstermektedirler. Politika uygulaması, ekonomik durumun gerektirdiği talebin gerisinde kaldığında faiz oranının gerçek değeri, kural değerinden sapmaktadır. Böyle bir istikrarsız para politikası rejiminde, enflasyon ya da deflasyonun ortaya çıkışı ve gelişimi kendi kendini besleyen bir mekanizmadır. Çalışmanın sonucunda faiz oranı reformunun ilerletilmesini ve orta hedef olarak para piyasası faiz oranı ile bir para politikası rejiminin oluşturulmasını önermektedirler.

Hutchisona, Senguptab, \& Singha (2013) çalışmalarında Hindistan Merkez Bankası için zamana bağlı bir Taylor tipi kuralı tahmini yapan Markov rejim değişim modeli kullanarak Hindistan'da para politikasındaki rejim değişimlerini araştırmaktadırlar. Çalışmada son 20 yılda para politikası oluşturulmasının iki rejimle karakterize edildiğini göstermişlerdir. Bunları "Şahin" ve "Güvercin" diye adlandırmaktadırlar. Bu rejimlerden ilkinde (Şahin) merkez bankası, çıktı açığının azaltılmak için enflasyon kontrolünde nispeten daha büyük bir ağırlığa sahiptir. 
Araştırma döneminin yarısında ise merkez bankası, enflasyonu azaltmak yerine ihracatı canlandırmak için döviz kuru hedeflemesi ve çıktı açığına odaklandığı Güvercin rejimi sürdürmektedir. Yazarlar son olarak birçok gelişmekte olan piyasalarda görülen yarı enflasyon hedeflemesi vurgusundan aşırı etkilenmeyen Hindistan'ın, para politikasının yürütülmesinde kendi yolunu takip ettiğini ifade ediyorlar.

Caporale vd (2016) çalışmalarında Endonezya, İsrail, Güney Kore, Tayland ve Türkiye ekonomileri için Taylor Kuralını ele almışlardır. Elde edilen sonuçlara göre politika yapıcıların enflasyon veya çıktı açığının hedeften sapmasına gösterdikleri tepki, tüm ülkelerdeki yüksek ve düşük enflasyon rejimleri için büyüklük ve / veya istatistiksel önem açısından farklııı gösterdiğini ortaya koymaktadır. Özellikle, döviz kurunu, ilk rejimde etkili değilken ikinci rejimde etkili olduğunu göstermişleridir. Genel olarak, geliştirilmiş doğrusal olmayan Taylor kuralının, bu ülkelerdeki politika yapıcıların davranışlarını daha doğru bir şekilde yansıttığını ifade etmektedirler.

\section{Türkiye özelinde Taylor kuralını inceleyen çalışmalar}

Berument \& Taşçı (2003), aylık verilerle Türkiye ekonomisi için 1990:01 ile 2000:10 döneminde ileriye dönük bir politika reaksiyon fonksiyonunu GMM çerçevesinde analiz etmektedirler. Çalışma sonucunda merkez bankasının enflasyonun ne beklenen ne de geçmiş değerlerini hedeflemediğini ve ilgili dönemde sanayi üretimini hedeflediğini göstermişlerdir.

Yazgan \& Yılmazkuday (2004), çalışmalarında Türkiye ve İsrail ekonomileri için ileriye dönük Taylor kuralı çerçevesinde aylık verilerle Türkiye için 2001M82004M4 dönemini ve İsrail için 1999M1-2002M12 dönemini GMM çerçevesinde tahmin etmektedirler. Sonuç olarak bu ülkelerde ve özellikle Türkiye'de ilgili dönemde para politikasının güçlü olduğu sonucuna ulaşmışlardır.

Aklan \& Nargeleçekenler (2008) çalışmalarında örtük enflasyon hedeflenmesinin başladığı 2002 sonrası dönem için (2002-2006) TCMB'nın geriye dönük politika reaksiyon fonksiyonunu Taylor kuralı çerçevesinde tahmin etmişlerdir. Elde edilen sonuçlara göre kısa vadeli faiz oranları Taylor kuralı çerçevesinde fiyat istikrarına uygun şekilde değişmektedir. Diğer bir ifade ile Taylor kuralı ilgili dönemde geçerlidir. Ayrıca TCMB'nın para politikası stratejisinin enflasyon açığı dışında üretim açığı ve döviz kuruna da tepki verdiğini ifade etmektedirler.
Onur (2008), Türkiye ekonomisi için 1980-2005 döneminde yıllık verilerle Granger nedensellik testi ve EKK analizi ile Taylor tipi bir reaksiyon fonksiyonu tahmin edilmiştir. Sonuç olarak faiz oranlarının enflasyonun belirlenmesinde önemli bir değişken olduğu sonucuna ulaşılmıştır.

Omay \& Hasanov (2010) çalışmalarında TCMB'nın 1990-2003 döneminde aylık verilerle STR (smooth transition functions) modeli yardımıyla ileriye ve geriye dönük politika reaksiyon fonksiyonlarını tahmin etmeye çalışmışlardır. Elde edilen sonuçlara göre ilgili dönemde TCMB'nın geriye dönük bir reaksiyon fonksiyonu takip ettiğini ortaya koymaktadırlar. Merkez bankası büyümeyi hızlandırmak için genişletici politikalar uyguladığı dönemlerde enflasyonu göz ardı etmekte ve daraltıcı politika uygulamasına gittiği dönemlerde ise fiyat istikrarını hedeflerken büyümeyi göz ardı ettiğini vurgulamaktadırlar.

Bilman \& Utkulu (2010) çalışmalarında Türkiye'de enflasyon açığı ve çıktı açığı arasındaki ilişkiyi Markov dönüşüm modeli kullanarak 1990:1-2008:5 dönemi için aylık verilerle araştırmaktadırlar. Çalışmanın ana katkısı Chen (2006) çalışmasını takip ederek rejim olasılıklarının tahmin edilmesidir. Çalışma sonucuna göre enflasyon açığı ve çıktı açığı arasındaki ilişkinin doğrusal olmadığını göstermişlerdir.

Lebe \& Bayat (2011), döviz kuru ile genişletilmiş Taylor Kuralı'nın geçerliliği, Türkiye ekonomisi için VAR analizi çerçevesinde 1986:5-2010:9 dönemi aylık verileri yardımıyla araştırılmıştır. Sonuç olarak merkez bankasının Taylor tipi bir reaksiyon fonksiyonu takip ettiği görülmüştür. Ayrıca çalışmada reeskont faiz oranının politika değişkeni olarak daha iyi sonuçlar verdiğini ifade etmektedirler.

Yapraklı (2011), sınır testi yaklaşımı ile 2001:82009:9 dönemini kapsayan aylık verilerle para politikası reaksiyon fonksiyonunu tahmin etmiştir. Sonuç olarak ilgili dönemde TCMB'nin politika sürecinde enflasyon yerine üretim açığını hedeflediklerini bunun yanı sıra döviz kurunun da göz önüne alındığını vurgulamaktadır.

Demirbaş \& Kaya (2012) çalışmalarında Türkiye'de 2001:8ve 2012:3 dönemini aylıkverilerle sınır testi yakIaşımı ile Taylor kuralının geçerliliğini araştırmışlardır. Sonuç olarak gecelik faiz oranının para politikası enstrümanı olarak kullanıldığı durumda Taylor kuralı çerçevesinde daha tutarlı sonuçlara ulaşıldığını ifade etmektedirler. Diğer bir ifade ile gecelik faiz oranları ile Taylor kuralının geçerli olduğunu göstermişlerdir. 
Kayhan, Bayat, \& Koçyiğit (2013) çalışmalarında TCMB'nin 2002-2011 yılları arasındaki para politikası stratejisi, King (1996) tarafından oluşturulan model çerçevesinde ileriye dönük bir reaksiyon fonksiyonu ile Markov rejim değişim yaklaşımıyla araştııı mıştır. Sonuç olarak Türkiye'de hızlı büyüme dönemlerinde merkez bankası asimetrik bir tutum takip etmektedir. Diğer bir ifade ile genişleme ve daralma dönemlerinde para politikası aktif ve pasif bir strateji takip etmiştir. Özellikle daralma dönemlerinde enflasyon hedeflemesi yanı sıra büyüme hedefli bir stratejinin takip edildiği ifade edilmektedir.

Çevik \& Pazarlığlu (2014) çalışmalarında, 1990:1-2013:3 dönemi Türkiye ekonomisinde para politikasının yapısını Markov Rejim Değişim yöntemi ile analiz etmişlerdir. 2001 yılında genel itibariyle para politikasının aktif rejim takip ettiği görülmüştür. Ancak takip edilen aktif rejim para politikasında istikrar kaybına neden olmuştur. 2001 sonrasında ise pasif bir para politikası rejimi takip edilmiştir. Yazarlar bunun sonucunda para politikasının istikrarlı bir yapıya sahip olduğunu ifade etmektedirler. Sonuç olarak TCMB, Taylor benzeri bir kural ile 2001 öncesi dönemde fiyat istikrarına dayalı ve 2001 sonrası dönemde ise fiyat ve finansal istikrarına dayalı bir politika takip etmektedir. Enflasyon yüksek seyrettiği dönemlerde ise enflasyon artışı faiz artışına neden olmaktadır.

Albayrak \& Abdioğlu (2015) çalışmalarında 20022014 döneminde TCMB'nın geriye ve ileriye dönük para politikası reaksiyon fonksiyonlarını tahmin etmeye çalışmaktadırlar. Sonuçlara göre merkez bankasının politika reaksiyonlarının üretim açığı yerine enflasyon açığına olduğunu göstermektedirler.

\section{Ekonometrik Model ve Analiz Sonuçları}

\subsection{Ekonometrik Model}

Taylor'un çalışmasından sonra, para politikası kuralı iktisat literatüründe oldukça ilgi görmüş ve buna istinaden, Taylor kuralının geçerliliği birçok gelişmiş ve gelişmekte olan ülke için ampirik olarak sınanmıştır. Bu çalışmalardan elde edilen sonuç Taylor kuralının Merkez Bankaları tarafından benimsendiği şeklindedir. Bununla birlikte, Merkez Bankası tepki fonksiyonundaki ağırlıkların her zaman $0.5^{\prime} \mathrm{e}$ eşit olmadığı, zamana ve ülkelere göre değişkenlik gösterebileceği belirlenmiştir. Diğer bir önemli nokta ise, orijinal Taylor kuralında enflasyon oranının hedeflenen değerden sapması geriye dönük yönteme göre hesaplanmakta, diğer bir ifadeyle dört dönemli gecikmeli enflasyon oranı ile hedeflenen enflasyon oranı arasındaki sapma dikkate alınmaktadır. Literatürde yer alan çalışmalar ise, Merkez Bankalarının enflasyon hedeflerini oluştururken geçmiş dönem enflasyon oranlarından ziyade beklenen enflasyon oranlarını dikkate aldığını göstermekte ve bu nedenle modelin ileriye yönelik versiyonu daha fazla tercih edilmektedir. Clarida vd. (1998) tarafından önerilerin ileriye yönelik Taylor kuralı rasyonel beklentiler teorisine dayanmakta ve Merkez Bankalarının hedef faiz oranlarını belirlerken $k$ dönem sonrası için enflasyon oranı hedefinden sapmayı ve $p$ dönem sonrası için hasıla açığından sapmayı dikkate aldıklarını belirlemişlerdir.

Merkez Bankaları genellikle kısa dönemli faiz oranlarını hedefledikleri düzeye yavaş bir şekilde ayarladıkları için (faiz oranı düzgünleştirmesi), faiz oranlarında yüksek düzeyde bir otokorelasyon olması beklenmektedir. Bu nedenle faiz oranı düzgünleştirmesi aşağıdaki gibi formüle edilmektedir:

Denklem (5)'teki gecikme uzunluğu hata terimlerini beyaz gürültü yapacak şekilde model bilgi kriterlerine göre belirlenmektedir. Denklem (2)'yi Denklem (5) içinde tekrar yazacak olursak politika kuralı aşağıdaki gibi yazılabilir:

Denklem (6)'nın ekonometrik olarak tahmin edilebilmesi için bir takım düzenlemeler yapmak gerekmektedir. İlk olarak, Assenmacher-Wesche (2006) reel faiz oranını ve enflasyon hedefini sabit terim içinde şu şekilde göstermiştir $\alpha=\bar{r}-(\beta-1) \pi^{*}$. Clarida vd. (1998) ise Denklem (6)'daki gözlenemeyen öngörü değişkenlerini modelden dışlayarak, para politikası kuralını reel değişkenlerle aşağıdaki gibi ifade etmiştir:

$$
\begin{aligned}
& i_{t}=\left(1-\sum_{i=1}^{n} \rho_{i}\right) i_{t}^{T}+\sum_{i=1}^{n} \rho_{i} i_{t-i} \text { burada } 0<\sum_{i=1}^{n} \rho_{i}<1 \\
& i_{t}=\left(1-\sum_{i=1}^{n} \rho_{i}\right)\left[\bar{r}+\pi^{*}+\beta\left(E \pi_{t+k}-\pi^{*}\right)+\gamma\left(E y_{t+p}-y_{t+p}^{*}\right)\right]+\sum_{i=1}^{n} \rho_{i} i_{t-i} \\
& i_{t}=\left(1-\sum_{i=1}^{n} \rho_{i}\right)\left[\alpha+\beta \pi_{t+k}+\gamma x_{t+p}\right]+\sum_{i=1}^{n} \rho_{i} i_{t-i}+\varepsilon_{t}
\end{aligned}
$$


burada $x_{t+p}$ hasıla açığını göstermekte ve hata terimi enflasyon oranı ve hasıla açığı öngörülerinin doğrusal kombinasyonu olarak aşağıdaki gibi ifade edilir:

Para politikası kuralının doğrusal formda olmadığı ve rejim değişim özelliği gösterdiği literatürde oldukça sık yer almaktadır. Örneğin, Altavilla ve Landolfo, 2005; Clarida vd., 1998 ve 2000; Kuzin, 2006; Assenmacher-Wesche, 2006; Zheng vd., 2012 Taylor kuralını tahmin etmede Markov rejim değişim modelini kullanmışlardır. Bu açıdan, Muscatelli vd. (2002) birçok ülke için kısa dönem faiz oranlarında yapısal kırılmaların varlığını tespit ederken, Judd ve Rudebusch (1998) ve Clarida vd. (2000) FED'in tepki fonksiyonunda enflasyon ve çıktı açığı için ağırlıkların başkanlara göre farklılık gösterdiğini belirlemişlerdir. Neumann ve von Hagen (1998) enflasyon ve çıktı açığı değişkenleri için katsayıların enflasyon hedeflemesine başlanan dönemde değiştiği sonucuna varmışlardır. Demers ve Rodriguez (2001), Kuzin (2006) ve Assenmacher-Wesche (2006) Taylor kuralını tahmin etmede Markov rejim değişim modelinin doğrusal modele göre daha üstün sonuçlar verdiğini belirlemişlerdir. Literatürde yer alan sonuçlara dayanarak bu çalışmada para politikası kuralı Markov rejim değişim modeli ile aşağıdaki gibi modellenmiştir:

burada $i_{t}$ nominal faiz oranı, $\pi_{t+k} t$ zamanında gelecekteki $k$ dönem için enflasyon oranı $x_{t+p} p$ dönem sonrası için hasıla açığını, $s_{t}$ gözlenemeyen rejim değişkenini ve $\varepsilon_{t}$ hata terimini göstermektedir. Çalışmada hasıla açığı Hodrick-Prescott filtresi kullanılarak reel GSYiH serisinden hesaplanmıştır. Denklem (9)'da gözlenemeyen rejim değişkeninin $\left(s_{t}\right)$ Hamilton (1994) tarafından aşağıdaki gibi birinci sıra Markov süreci olarak tanımlanır:

$$
\begin{aligned}
& \varepsilon_{t} \equiv-\left(1-\sum_{i=1}^{n} \rho_{i}\right)\left[\beta\left(\pi^{*}-E \pi_{t+k}\right)+\gamma\left(y_{t+p}^{*}-E y_{t+p}\right)\right]+v_{t} \\
& i_{t}=\alpha\left(s_{t}\right)+\beta \pi_{t+k}\left(s_{t}\right)+\gamma x_{t+p}\left(s_{t}\right)+\sum_{i=1}^{n} \rho_{i} i_{t-i}\left(s_{t}\right)+\varepsilon_{t} \\
& P\left[s_{t}=\left.1\right|_{t-1}=1\right]=p_{11} \\
& P\left[s_{t}=\left.1\right|_{t-1}=2\right]=1-p_{11} \\
& P\left[s_{t}=\left.2\right|_{s_{t-1}}=2\right]=p_{22} \\
& P\left[s_{t}=\left.2\right|_{s_{t-1}}=1\right]=1-p_{22} \\
& 0<p_{11}<1 \quad 0<p_{22}<1
\end{aligned}
$$

burada $p_{i j}$ rejimler için sabit geçiş olasıllklarını göstermektedir ve rejimlerde ortalama kalma süreleri $d=1 /\left(1-p_{i i}\right)$ şeklinde hesaplanmaktadır. Çalışmada para politikası kuralının iki rejimli olduğu varsayılarak, enflasyon oranı için tahmin edilen katsayısının birden büyük olduğu rejim $(\beta \geq 1)$ aktif para politikasının uygulandığı rejim olarak adlandırıımıştır. Diğer taraftan, enflasyon oranı için tahmin edilen ağırlığın birden küçük olduğu dönemler ise $(\beta<1)$ pasif para politikası rejimi olarak adlandırılmıştır.

\subsection{Veri ve Analiz Sonuçları}

Çalışmada Taylor para politikası kuralı modelini tahmin etmek için 1999 ile 2014 yılları arasında üçer aylık veriler kullanılmıştır. Politika faiz oranı için bankalararası gecelik faiz oranları dikkate alınırken, yıllık enflasyon oranları Tüketici Fiyat Endeksinden hesaplanmıştır. Hasıla açığı değişkeni ise reel GSYiH serisinden HP filtresi kullanılarak elde dilmiştir.' Değişkenlerin tümü TCMB elektronik veri dağıtım sisteminden temin edilmiş olup, olası mevsimsel etkiler Tramo-Seats yöntemi kullanılarak arındırılmıştır.

Denklem (9) gösterilen para politikası kuralının Markov rejim değişim modeli ile tahmin edebilmesi için öncelikle faiz oranı düzgünleştirmesi için optimal gecikme sayısının belirlenmesi gerekmektedir. Birden dörde kadar farklı gecikmeler için model tahmin edilmiş ve hata terimlerini beyaz gürültü yapan 
gecikme sayısının bir olduğuna karar verilmiştir. íkinci olarak ileriye yönelik para politikası kuralını tahmin edebilmemiz için optimal $k$ ve $p$ değerlerinin belirlenmesi gerekir. Bu nedenle 1'den 4'e kadar tüm değerler dikkate alınarak tüm olası model kombinasyonları denenmiş ve optimal $k$ ve $p$ değerleri model seçim kriterleri ve katsayıların iktisadi beklentilere uyumu dikkate alınarak 3 olarak elde edilmiştir. Bu sonuca göre, TCMB kısa dönem faiz oranlarını belirlerken 3 dönem sonrası enflasyon oranı ve hasıla açığını dikkate almaktadır.

TCMB tarafından uygulanan para politikası kuralının doğrusal yapıda olmaması (diğer bir ifadeyle ekonomik konjonktüre göre enflasyon ve hasıla açı̆̆ına farklı ağırlıklar vermesi) durumunda iki durumlu Markov rejim modelinin veriyi temsil etmede doğrusal modele göre daha iyi sonuç vermesi beklenir. Modellerin veriyi temsil etme performansı Olabilirlik Oranı (Likelihood Ratio-LR) testi ile araştırılmıştır. Sıfır hipotezin doğrusal model ve Markov rejim değişim modelinden elde edilen parametre tahminleri arasında anlamlı bir farklılık yoktur şeklinde kurulduğu test yönteminde, test istatistiği ki-kare dağılımına uymaktadır. LR test istatistiği 49.721 (p-değeri 0.000) olarak bulunmuş ve bu sonuç \%1 anlamlılık düzeyinde sıfır hipotezin reddedilmesine imkan sağlamıştır. Bu nedenle, LR testi sonucunda Markov rejim değişim modelinin para politikası kuralını tahmin etmede daha iyi sonuç verdiği belirlenmiştir. 1999-2014 dönemi için model tahmin sonuçları Tablo 1'de gösterilmiştir.

Tablo 1'deki sonuçlara göre, öncelikle faiz oranı düzgünleştirmesi için gecikmeli faiz oranı değişkeni hem rejimlere göre değişen hem de rejimlere göre sabit olarak tahmin edilmiş ve rejimlere göre sabit olarak tahmin edilen modelin daha iyi sonuç verdiği görülmüştür. İkinci olarak 2001 yılının Şubat ayında ortaya çıkan krizin etkisini dikkate alabilmek için 2001 yılının ilk çeyreğinde bir değerini alan kukla değişken modele eklenmiştir. Markov rejim değişim modelinden elde edilen tahmin sonuçlarına göre, rejimler tahmin edilen $\beta$ katsayısına göre pasif ve aktif para politikası rejimi olarak adlandırılımıştır. Buna göre, her ne kadar ilk rejimde $\beta$ katsayısı 1.050 olarak tahmin edilse de istatistiksel olarak birden büyük elde edilememiştir. Diğer taraftan ikinci rejimde $\beta$ katsayısı 1.489 olarak tahmin edilmiş ve istatistiksel olarak birden büyük bulunmuştur. Çıktı açığı değişkenin katsayısı $(\gamma)$ ilk rejimde 1.567 olarak tahmin edilmiş ve istatistiksel olarak anlamlı bulunurken, ikinci rejimde katsayı tahmini 0.193 olarak bulunmuş ve istatistiksel olarak sıfırdan farklı olmadığı görülmüştür. Tablo 1'de yer alan sonuçlara göre, TCMB birinci rejimde faiz oranlarını ayarlarken enflasyon oranından ziyade çıktı açığına daha fazla önem verdiği, ikinci rejimde ise enflasyon oranına daha fazla önem verdiği görülmektedir. Rejimlerin geçiş olasılıkları incelendiğinde pasif para politikası rejiminin daha yüksek bir kalıcılığa sahip olduğu görülmekte ve bu sonuca paralel olarak pasif para politikası rejiminde ortalama kalma süresi 9.5 çeyrek iken, aktif para politikası rejiminde ortalama kalma süresi 8.33 çeyrek olarak tahmin edilmiştir.

Tablo 2: Para Politikası Kuralı Model Sonuçları

\begin{tabular}{|c|c|c|c|c|}
\hline \multirow[b]{2}{*}{$a\left(s_{t}\right)$} & \multicolumn{2}{|c|}{$\begin{array}{l}\text { Rejim 1: Pasif Para } \\
\text { Politikası }\end{array}$} & \multicolumn{2}{|c|}{$\begin{array}{l}\text { Rejim 2: Aktif Para } \\
\text { Politikası }\end{array}$} \\
\hline & $-0.026^{*}$ & $(0.014)$ & $0.070^{* *}$ & $(0.030)$ \\
\hline$\beta\left(s_{t}\right)$ & $1.050^{* * *}$ & $(0.088)$ & $1.489 * * *$ & $(0.111)$ \\
\hline$Y\left(s_{t}\right)$ & $1.567^{* * *}$ & $(0.361)$ & 0.193 & $(0.471)$ \\
\hline$\sigma\left(s_{t}\right)$ & \multicolumn{2}{|c|}{0.043} & \multicolumn{2}{|c|}{0.059} \\
\hline $\boldsymbol{p}_{i j}$ & \multicolumn{2}{|c|}{0.910} & \multicolumn{2}{|c|}{0.879} \\
\hline$d$ & \multicolumn{2}{|c|}{9.5} & \multicolumn{2}{|c|}{8.33} \\
\hline$\rho_{1}$ & \multicolumn{4}{|c|}{$0.099^{* *}(0.042)$} \\
\hline$K_{\text {Kukla }} 2001$ & \multicolumn{4}{|c|}{$0.801^{* * *}(0.078)$} \\
\hline $\mathbf{P}-\mathbf{X}^{2}$ & \multicolumn{4}{|c|}{19.439 [0.053] } \\
\hline $\mathrm{N}-\mathrm{X}^{2}$ & \multicolumn{4}{|c|}{$2.062[0.356]$} \\
\hline$H-X^{2}$ & \multicolumn{4}{|c|}{$12.747[0.000]$} \\
\hline
\end{tabular}

Not: Parantez içindeki değerler standart hatayı göstermektedir. $\sigma$ $\left(s_{t}\right)$ regresyonun standart hatasıdır. $\mathrm{p}_{\mathrm{ii}}$ rejim geçiş olasılıklarını, $\mathrm{d}$ rejimlerin ortalama kalıcılığını göstermektedir. $\mathrm{P}-\mathrm{X}^{2}$ hata terimleri için Portmanteau seri korelasyon testini, $\mathrm{N}-\chi^{2}$ normal dağılım testini ve $\mathrm{H}-\chi^{2}$ hata terimleri için değişen varyans testini göstermektedir. $* * *, * *$ ve * \%1, \%5 ve \%10 önem düzeylerinde istatistiksel olarak anlamlı katsayıları göstermektedir.

Grafik 3'te aktif para politikası rejimi için düzgünleştirilmiş geçiş olasılıkları ile birlikte TCMB tarafından hedeflenen enflasyon oranı ile gerçekleşen enflasyon oranları yer almaktadır. Düzgünleştirilmiş geçiş olasılıkları hangi dönemlerde TCMB tarafından aktif para politikasının uygulandığını göstermektedir. Buna göre, ele alınan örneklem dönemi içinde üç farklı dönemde aktif para politikasının uygulandığı görülmektedir. Illk dönem 2000 yılının son çeyreği ile 2001 yılının ilk çeyreğidir. İkinci dönem 2001Q3 ile 2005Q1 arasında olup 15 çeyrek dönemi kapsamaktadır. Son dönem ise 2007Q2 ile 2009Q1 arasındadır. Bilindiği üzere TCMB 2001 krizinin ardından uyguladığı para politikasında değişikliğe giderek para politikası stratejisi olarak enflasyon hedeflemesini benimsemiştir ve 2001-2005 yılları arasında 
enflasyon hederlerini tutturabilmek için aktif para politikası uygulandığı görülmektedir. 2005-2006 yıllarında TCMB'nin aktif para politikası uygulamaktan vazgeçtiği görülmekte ve bu tarihten itibaren enflasyon hedeflerinden sapmalar ortaya çıkmaktadır. Her ne kadar 2007-2009 yılları arasında tekrar aktif para politikası uygulanmaya başlasa da, söz konusu dönemde 2009 yılı hariç olmak üzere enflasyon hedeflerinin gerçekleştirilemediği görülmektedir. ABD'de başlayan küresel finansal krizin gelişmiş ve gelişmekte olan ülkelere yansımasıyla birlikte birçok Merkez Bankası açısından enflasyon ikincil sorun haline dönüşerek makro ihtiyati politikalar ön plana çıkmıştır. Bu bağlamda TCMB 2009 yılından itibaren hasıla açığına daha fazla önem veren bir politika tercihine yönelmiş görülmektedir.

Çalışmada ele alınan temel soru merkez bankası para politikası tercihleri ile işsizlik oranları arasındaki ilişki olduğundan, aktif para politikası rejimi ile işsizlik oranları Grafik 4'te gösterilmiştir. Buna göre, TCMB'nin para politikası tercihleri ile işsizlik oranları arasında anlamlı bir ilişki olabileceği Grafik 4'te görülmektedir. Şöyle ki, TCMB'nin aktif para politikasını uyguladığı dönemlerde işsizlik oranlarında keskin artışlar gözlenmiştir. Örneğin, 2001 krizi öncesi \%6 civarındaki işsizlik oranları 2001 kriziyle birlikte \%10'lar seviyesine yaklaşmıştır. Benzer şekilde küresel krizin ülke ekonomisine yansıdığı yıl olan 2009 öncesinde $\% 10^{\prime}$ lar düzeyinde olan işsizlik oranları 2009 yılında \%13 seviyesine kadar yükselmiştir. Burada dikkate edilmesi gereken durum ise, aktif para politikasının uygulandığı dönemlerde hasıla açığı değişkenin katsayısının istatistiksel olarak anlamsız olduğudur. Diğer bir ifadeyle, aktif para politikasının uygulandığı dönemlerde TCMB sadece ve sadece enflasyon oranını dikkate alarak faiz oranlarını belirlemiştir.

Burada merak uyandıran bir soru ise, TCMB söz konusu dönemlerde enflasyon oranının yanında hasıla açığını da dikkate alan politika kombinasyonu uygulasaydı (örneğin pasif para politikası gibi) işsizlik oranları bu kadar yükselir miydi ya da enflasyon oranları daha yüksek olur muydu? Bu sorulara cevap verebilmek için çalışmamızda eğilim skoru eşleştirme (propensity score matching-PSM) yöntemi uygulanmıştır.

PSM özellikle tıp literatüründe oldukça sık kullanılan bir yöntemdir ve uygulanan bir tedavi yönteminin veya ilacın, tedavi grupları ile kontrol grupları arasındaki ilişkisini açıklamaya yönelik geliştirilmiştir. PSM özelikle son yıllarda iktisat literatüründe yer bulmaya başlamış ve enflasyon hedeflemesi uygulayan ve uygulamayan ülkeler açısından, enflasyon hedeflemesi programının başarısını ölçmek için kullanılmaktadır (örneğin, Lin ve Ye, 2007; Crowe, 2006). Bu çalışmada ise söz konusu bu çalışmalardan farklı olarak para politikası tercihinin işsizlik oranları üzerindeki etkisi analiz edilecektir. Bu bağlamda, tedavi grubu, aktif para politikasının uygulandığı (enflasyona daha fazla ağırlık verildiği) dönemler ve kontrol grubu ise pasif para politikasının uygulandığı (hasıla açığına daha fazla önem verildiği) dönemler olarak adlandırılırsa, ortalama tedavi etkisi (ATT) aşağıdaki gibi tahmin edilir:

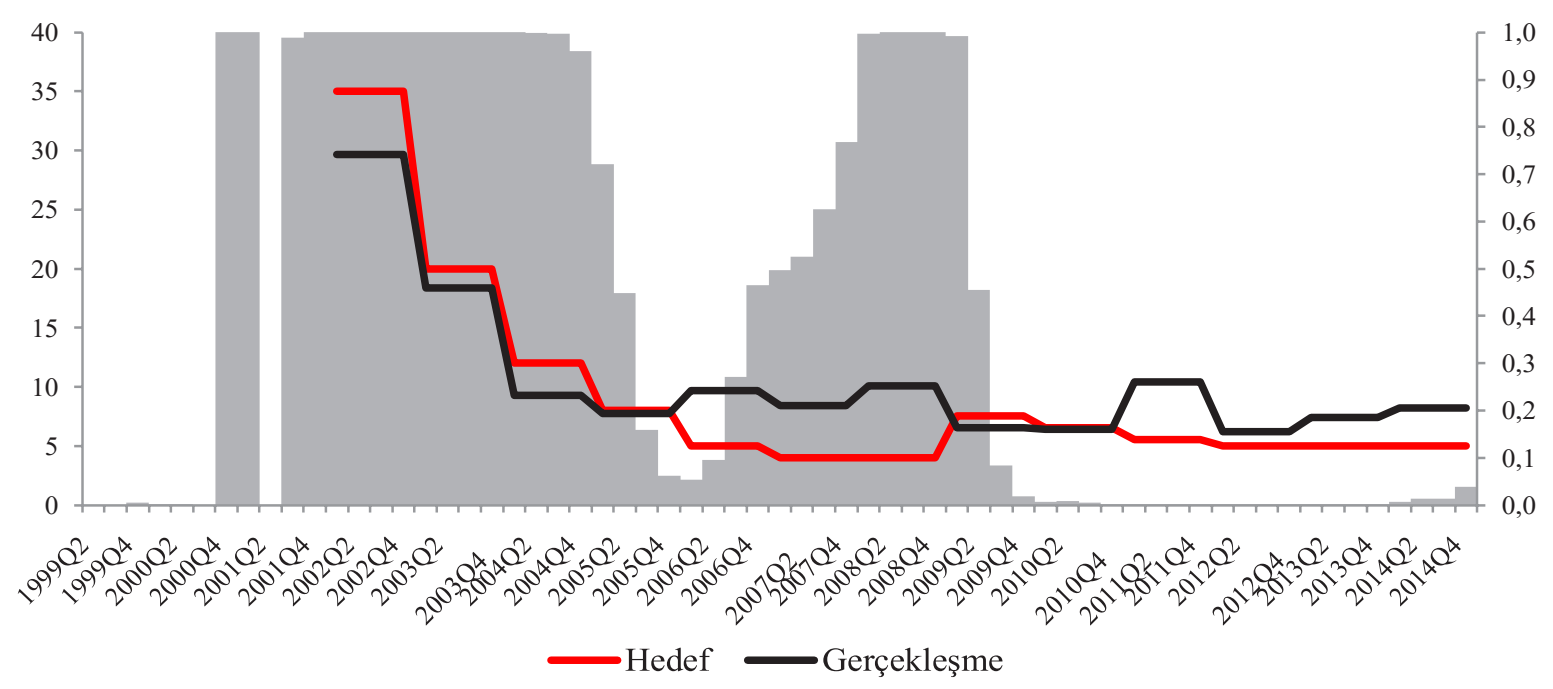

Grafik 3: Aktif Para Politikası Dönemleri, Hedeflenen ve Gerçekleşen Enflasyon Oranı 


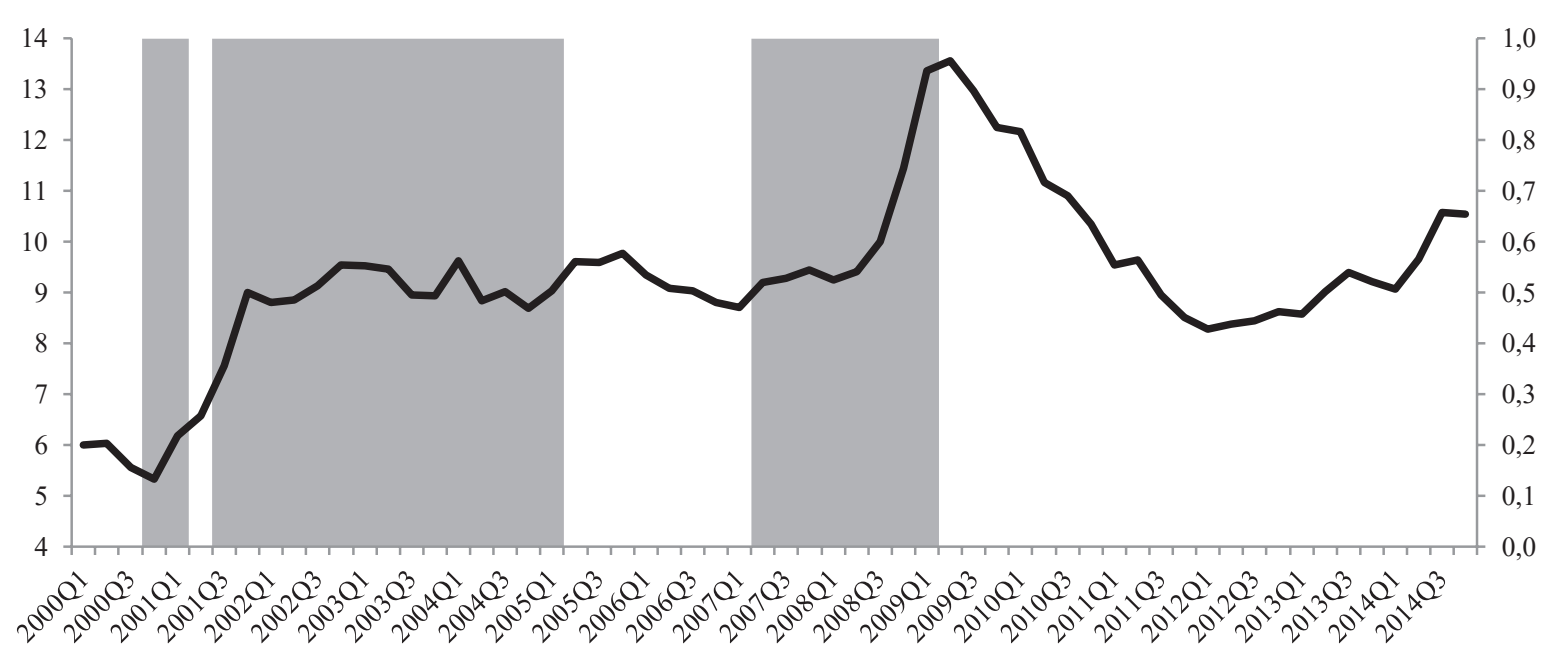

—işsizlik Oranı

Grafik 4: Aktif Para Politikası Dönemleri ve Işsizlik Oranı

$$
A T T=E\left[Y_{i 1} \mid D_{i}=1\right]-E\left[Y_{i 0} \mid D_{i}=1\right]
$$

Denklem (11)'de $D_{i}$ kukla değişken olup aktif para politikasının uygulandığı dönemler için 1 , diğer dönemler için sıfır değerini almaktadır. $Y$ sonuç değişkeni olarak tanımlanmakta ve işsizlik oranını göstermektedir. $Y_{i 0} \mid D_{i}=1$ söz konusu dönemde aktif para politikası uygulanmasaydı işsizlik oranlarının ne olabileceğini gösteren sonucu temsil ederken, $Y_{i 1} \mid D_{i}=1$ ise aktif para politikası dönemlerindeki işsizlik oranlarını göstermektedir. ATT'nin tahmin edilmesindeki en büyük sorun, Denklem (11)'in sağ tarafındaki ikinci terimin gözlenemiyor olmasıdır. Çünkü söz konusu dönemde TCMB politika tercihini, aktif para politikasından yana kullanmıştır. Bununla birlikte, TCMB'nin politika tercihi tesadüfi bir şekilde ortaya çıkmış olsa idi, aktif ve pasif para politikası dönemleri için örnek ortalamalarını kullanarak bir karşılaştırma yapabilirdik. Fakat, böyle bir yöntem para politikası tercihlerinin tesadüfi olmadığında sapmalı sonuçlar verecektir.

Veri seçim sorununu çözmek için, tedavi etkisi ölçüm literatüründe oldukça sık kullanılan eğilim skoru eşleştirme yöntemi kullanabilir. Eşleştirme yönteminde esas nokta bir kontrol grubu kullanarak tesadüfi olarak gerçekleştirilmiş bir deneyi tekrarlanabilir hale getirmektedir. Eşleștirme yönteminin temel varsayımı $\left(Y_{0}, \quad Y_{1} \perp D \mid X\right)$ şeklinde gösterilebilir ve bu varsayım, para politikası tercihlerinin $X$ değişkenine koşullu olarak bağımlı olmasının yanında, sonuç değişkenin para politikası tercihleri için oluşturulan kukla değişkenden bağımsız olmasını gerektirir. Bu varsayım altında Denklem (11) aşağıdaki gibi tekrar yazılabilir:

Denklem (12)'de $E\left[Y_{i 0} \mid D_{i}=1, X_{i}\right]$, gözlemlenebilir olan $E\left[Y_{i 0} \mid D_{i}=0, X_{i}\right]$ ile yer değiştirmiştir. Eşleştirme yöntemi, $X^{\prime}$ in benzer değerlerini kullanarak tedavi birimlerinin kontrol birimleri ile eşleştirme işlemidir. $X$ değişkenlerinin sayısının artması durumunda, bu yöntemin pratikte uygulanması güçlük yaratabilir. Bu sorunun üstesinden gelebilmek için X'e bağlı olarak aktif para politikası uygulanma olasılıkları logit veya probit model kullanılarak tahmin edilebilir. Buna göre, ATT değerleri eğilim skoru eşleştirme yöntemi kullanılarak aşağıdaki gibi hesaplanabilir:

$$
\begin{aligned}
& A T T=E\left[Y_{i 1} \mid D_{i}=1, X_{i}\right]-E\left[Y_{i 0} \mid D_{i}=1, X_{i}\right] \\
& A T T=E\left[Y_{i 1} \mid D_{i}=1, p\left(X_{i}\right)\right]-E\left[Y_{i 0} \mid D_{i}=1, p\left(X_{i}\right)\right]
\end{aligned}
$$


Eğilim skoru eşleştirmesi için literatürde farklı yaklaşımlar bulunmaktadır. Bu çalışmada, en yakın komşu eşleştirmesi ( $n=1$ ve 3 için) ile kernel eşleştirme yöntemi kullanılmıştır. Eğilim skoru eşleştirme sonuçları Tablo 3'de gösterilmiştir. ${ }^{2}$ Buna göre, en yakın komşu eşleştirme ve kernel eşleştirme yöntemlerine göre ATT değerleri pozitif ve istatistiksel olarak anlamlı bulunmuş ve ortalama ATT değeri 0.011 olarak hesaplanmıştır. Bu sonuç, TCMB'nin para politikası tercihleri ile işsizlik oranları arasında istatistiksel olarak anlamlı bir ilişki olduğu ve aktif para politikasının uygulandığı dönemlerde pasif para politikasının uygulandığı dönemlere göre işsizlik oranının ortalama \%1.1 daha fazla olduğu anlamına gelmektedir.

Tablo 3: Eğilim Skoru Eşleştirme Sonuçları

\begin{tabular}{l|c:c:c}
\hline & $\begin{array}{c}\text { En Yakın } \\
\text { Komşu } \\
\text { Eşleştirmesi }\end{array}$ & $\begin{array}{c}\text { En Yakın } \\
\text { Komşu } \\
\text { Eşleştirmesi (3) }\end{array}$ & $\begin{array}{c}\text { Kernel } \\
\text { Eşleştirmesi }\end{array}$ \\
\hline \hline ATT & $0.014^{* * *}$ & $0.012^{* * *}$ & $0.009^{*}$ \\
Tedavi & $(0.004)$ & $(0.004)$ & $(0.005)$ \\
Kontrol & 25 & 25 & 19 \\
Toplam & 35 & 35 & 35 \\
\hline
\end{tabular}

Not: Parantez içindeki değerler standart hataları göstermektedir. *** ve * \%1 ve \%10 önem düzeyinde istatistiksel olarak anlamlı katsayıyı göstermektedir.

\section{SONUÇ}

Küresel krizle beraber merkez bankalarının para politikası uygulamalarının etkinliği yaygın bir tartışma konusu haline gelmiştir. İhtiyari ve kurala bağlı politika tartışmaları bağlamında Taylor kuralı, merkez bankalarının başvurabileceği bir kurala bağlı para politikası stratejisi olarak karşımıza çıkmaktadır.

Bu strateji, merkez bankasının kısa dönemli istikrar hedefi ile uzun dönemli fiyat istikrarı hedefine ulaşmak için para politikası aracı olarak faizi nasıl kullanması gerektiğine dair bir öneri sunmaktadır. Taylor kuralı, merkez bankasının uyguladığı para politikasını hem tanımlayan hem de öngören bir stratejidir. Literatürde Taylor kuralının etkinliğine ilişkin çalışmalar incelendiğinde bir konsensüs oluşmadığı görülmektedir.

Çalışmamızda Taylor tarafından geliştirilen para politikası kuralı modeli, 1999 ile 2014 yılları arasında
Türkiye ekonomisinin üçer aylık verileri ile tahmin edilmektedir. Politika faiz oranı için bankalararası gecelik faiz oranları dikkate alınırken, yıllık enflasyon oranları Tüketici Fiyat Endeksinden hesaplanmıştır. Hasıla açı̆̆ı değişkeni ise reel GSYiH serisinden HP filtresi kullanılarak elde dilmiştir.

Ele alınan örneklem dönemi içinde TCMB tarafından üç farklı dönemde aktif para politikasının uygulandığı görülmektedir. İlk dönem 2000 yılının son çeyreği ile 2001 yılının ilk çeyreğidir. İkinci dönem 2001Q3 ile 2005Q1 arasında olup 15 çeyrek dönemi kapsamaktadır. Son dönem ise 2007Q2 ile 2009Q1 arasındadır. ABD'de başlayan küresel finansal krizin gelişmiş ve gelişmekte olan ülkelere yansımasıyla birlikte birçok Merkez Bankası açısından enflasyon ikincil sorun haline dönüşerek makro ihtiyati politikalar ön plana çıkmıştır. Bu bağlamda TCMB 2009 yılından itibaren hasıla açığına daha fazla önem veren bir politika tercihine yönelmiş görülmektedir.

Çalışmada ele alınan temel soru ise, merkez bankası para politikası tercihleri ile işsizlik oranları arasındaki ilişkidir. TCMB'nin aktif para politikası uyguladığı dönemlerde işsizlik oranlarında keskin artışlar mevcuttur. Örneğin, 2001 krizi öncesi \%6 civarındaki işsizlik oranları 2001 kriziyle birlikte \%10'lar seviyesine yaklaşmıştır. Benzer şekilde küresel krizin ülke ekonomisine yansıdığı yıl olan 2009 öncesinde \%10'lar düzeyinde olan işsizlik oranları 2009 yılında \%13 seviyesine kadar yükselmiştir. Burada dikkate edilmesi gereken durum ise, aktif para politikasının uygulandığı dönemlerde hasıla açığı değişkenin katsayısının istatistiksel olarak anlamsız olduğudur. Diğer bir ifadeyle, aktif para politikasının uygulandığı dönemlerde TCMB, faiz oranlarını sadece ve sadece enflasyon oranını dikkate alarak belirlemiştir.

Burada karşımıza merak uyandıran bir soru çıkmaktadır. TCMB söz konusu dönemlerde enflasyon oranının yanında hasıla açığını da dikkate alan politika kombinasyonları uygulasaydı (örneğin pasif para politikası gibi) işsizlik oranları bu kadar yükselir miydi ya da enflasyon oranları daha yüksek olur muydu? $\mathrm{Bu}$ sorulara cevap verebilmek için çalışmamızda eğilim skoru eşleştirme yöntemi uygulanmıştır. Buna göre, en yakın komşu eşleştirme ve kernel eşleştirme yöntemlerine göre ATT değerleri pozitif ve istatistiksel olarak anlamlı bulunmuş ve ortalama ATT değeri 0.011 olarak hesaplanmıştır. Bu sonuç,

${ }^{2} A k t i f$ para politikası rejim olasılıkları için logit model tahmin edilirken, enflasyon oranının bir dönem gecikmeli değeri, ticari açıklık, dolar kuru, yurtiçi kredi hacmi değişkenleri dikkate alınmış fakat sadece enflasyon oranının bir dönem gecikmeli değeri iktisadi ve istatistiki kriterlere göre anlamlı bulunmuştur. 
TCMB'nin para politikası tercihleri ile işsizlik oranları arasında istatistiksel olarak anlamlı bir ilişki olduğu ve aktif para politikasının uygulandığı dönemlerde pasif para politikasının uygulandığı dönemlere göre işsizlik oranının ortalama \%1.1 daha fazla olduğu anlamına gelmektedir.

\section{KAYNAKÇA}

Agur, I., \& Demertzis, M. (2013). Leaning Against the Wind" and the Timing of Monetary Policy. IMF Working Paper(WP/13/86).

Aizenman, J., Hutchison, M., \& Noy, I. (2011). Inflation Targeting and Real Exchange Rates in Emerging Markets. World Development, 39(5), 712-724.

Aklan, N., \& Nargeleçekenler, M. (2008). Taylor Kuralı: Türkiye Üzerine Bir Değerlendirme. Ankara Üniversitesi SBF Dergisi, 63(2).

Albayrak, N., \& Abdioğlu, Z. (2015). Geriye Ve Illeriye Dönük Para Politikası Reaksiyon Fonksiyonlarının Tahmini: Taylor Kuralı. Süleyman Demirel Üniversitesi IiBFF Dergisi, 20(4), 141-163.

Altavilla, C., \& Landolfo, L. (2005). Do central banks act asymmetrically? Empirical evidence from the ECB and the Bank of England. Applied Economics, 37(5), 507 519.

Ardor, H., \& Varlık, H. (2014). Ileriye Dönük Yeni Keynesyen Para Politikası Reaksiyon Fonksiyonunun Tahmini: Taylor Kuralı'nın, Mccallum Kuralı'nın, TaylorMccallum Melez Kuralı́nın Türkiye Ekonomisinde Geçerliliği. Ekonomik Yaklaşım, 24(89), 45-71.

Assenmacher-Wesche, K. (2016). Estimating Central Banks' preferences from a time-varying empirical reaction function. European Economic Review, 50, 19511974.

Ball, L. (1999). Policy Rules for Open Economies. J. B. Taylor içinde, Monetary Policy Rules (s. 127 - 156). University of Chicago Press.

Ball, L., \& Tchaidze, R. (2002). The Fed and the New Economy. American Economic Review, 92, 108-114.

Bec, F., Salem, M. B., \& Collard, F. (2002). Asymmetries in Monetary Policy Reaction Function Evidence for the U.S., French and German Central Banks. Studies in Nonlinear Dynamics and Econometrics, 6(2).

Berument, H., \& Taşçı, H. (2003). Monetary Policy Rules in Practice Evidence from Turkey. International Journal of Finance \& Economics.

Bilman, A., \& Utkulu, U. (2010). Inflation And Output Gaps Reconsidered: Assymetries And Nonlinear Phillips Curve Evidence For The Turkish Economy. Journal of Yasar University, 3155 - 3170.

Caporale, G., Catik, N., Helmi, M., Menla Ali, F., \& Akdeniz, C. (tarih yok). Monetary Policy Rules in Emerging Countries: Is There an Augmented Nonlinear Taylor Rule? CESifo Working Paper Series(5965).
Carare, A., \& Tchaidze, R. (2005). The Use and Abuse of Taylor Rules: How Precisely Can We Estimate Them? IMF Working Paper(WP/05/148).

Chen, Y., \& Huo, Z. (2009). A Conjecture of Chinese Monetary Policy Rule: Evidence from Survey Data, Markov Regime Switching, and Drifting Coefficients. Annals of Economics And Finance(10-1), 111-153.

Christoper, C. (2006). Testing the Transparency Benefits of Inflation Targeting. IMF Working Paper. IMF.

Clarida, R., Gali, J., \& Gertler, M. (1998). Monetary policy rules in practice: Some international evidence. European Economic Review(46), 1033-1067.

Clarida, R., Gali, J., \& Gertler, M. (2000). Monetary Policy Rules and Macroeconomic Stability: Evidence and Some Theory. Quarterly Journal of Economics, 115, 147-180.

Çevik, N., \& Pazarlıoğlu, V. (2014). Türkiye'de Para Politikasının Yapısı Ve Para Kuralı: 2013-1990 Dönemi. Balkan Sosyal Bilimler Dergisi, 3(6).

Demers, F., \& Rodriguez, G. (2001). Estimation of the Taylor rule for Canada under multiple structural changes. Mimeo, University of Ottawa, Cahier de travail, 0107E.

Demirbaş, E., \& Kaya, M. (2012). Testing the Validity of Taylor Principle for Turkey from a Different Perspective. AiBÜ Sosyal Bilimler Enstitüsü Dergisi, 12, 81-110.

Erdoğan, S. (2013). Para Politikası. Kocaeli: Umuttepe.

Erdoğan, S., Yıldırım, D. Ç., \& Güneş, H. (2010). Enflasyon Hedeflemesi Stratejisi. Maliye Dergisi(159).

Hutchisona, M., Senguptab, R., \& Singha, N. (2013). Dove or Hawk? Characterizing monetary policy regime switches in India. Emerging Markets Review, 16, 183-202.

Islam, M., \& Ali, M. (2012). Taylor Principle Supplements the Fisher Effect: Empirical Investigation under the US Context. Economia. Seria Management(15), 189-203.

Judd, J., \& Rudebusch, G. (1998). Taylor's rule and the fed: 1970-1997. (3), . Federal Reserve Bank of San Francisco, Economic Review, 3, 3-16.

Kayhan, S., Bayat, T., \& Koçyiğit, A. (2013). Enflasyon Hedeflemesi Rejiminde Öğrenme Süreci ve Asimetri: Markov Switching Yaklaşımı. Eskişehir Osman Gazi Üniveristesi IiBF Dergisi (8 (1)), 191-212.

Kim, C., \& Nelson, C. (2006). Estimation of a ForwardLooking Monetary Policy. Journal of Monetary Economics(53), 1949-1966. 
King, M. (1996). How should central banks reduce inflation? Conceptual issues. Federal Reserve Bank of Kansas City.

Kuzin, V. (2006). The Inflation Aversion of the Bundesbank: A State-Space Approach. Journal of Economic Dynamics and Control(30), 1671-1686.

Lebe, F., \& Bayat, T. (2011). Taylor Kuralı: Türkiye İçin Bir Vektör Otoregresif Model Analizi. Ege Akademik Bakış, 11, 95-112.

Lin, S., \& Ye, H. (2007). Does inflation targeting really make a difference? Evaluating the treatment effect of inflation targeting in seven industrial countries. Journal of Monetary Economics, 54, 2521-2533.

Martin, C., \& Milas, C. (2010). Financial Stability and Monetary Policy. Working Paper. Bath, U. K.: Department of Economics, University of Bath (Working Papers; 05/10).

Muscatelli, V., Tirelli, P., \& Trecroci, C. (2002). Does institutional change really matter? Inflation targets, Central Bank Reform and Interest Rate Policy in the OECD Countries. Manchester Schoo, 70(4), 487-527.

Neumann, M., \& von Hagen, J. (2002). Does inflation targeting matter? Zentrum für Europaische Integration Forschung, B01.

Omay, T., \& Hasanov, M. (2010). Türkiye İçin Reksiyon Fonksiyonunun Doğrusal Olmayan Modelle Tahmin Edilmesi. Çankaya University Journal of Humanities and Social Sciences, 7(2), 467-490.

Onur, S. (2008). Türkiye Ekonomisi'nde Faiz OranlarıEnflasyon illişkisi Üzerine Bir Model Denemesi (19802005). Journal of Qafquaz University, 24, 123-145.

Orphanides, A. (1997). Monetary Policy Rules Based on Real-Time Data. Board of Governors of the Federal Reserve System.

Orphanides, A. (2001). Monetary Policy Rules Based on Real-Time Data. American Economic Review, 91(4), 964-985.

Orphanides, A. (2002). Monetary Policy Rules and the Great Inflation. Board of Governors of the Federal Reserve System.
Orphanides, A. (2007). Taylor Rules. Board of Governors of the Federal Reserve System.

Orphanides, A., \& Williams, C. (2003). Robust Monetary Policy Rules with Unknown Natural Rates. Finance and Economics Discussion Paper Series, 2003-11.

Perruchoud, A. (2009). Estimating a Taylor Rule with Markov Switching Regimes for Switzerland. Swiss Journal of Economics and Statistics (SJES) , 145(2), 187220.

Shi, Z. (2012). Empirical Analysis of Chinese Monetary Policy Rules on Forward-looking Taylor Reaction Function. Journal of Convergence Information Technology(JCIT), 7(14).

Sims, C., \& Zha, T. (2006). "Were There Regime Switches in U.S. Monetary Policy? American Economic Review, 96(1), 54-81.

Taylor, J. (1993). Discretion Versus Policy Rules in Practice. Carnegie-Rochester Conference Series on Public Policy, 39, s. 195-214.

Taylor, M., \& Davradakis, E. (2006). Interest Rate Setting and Inflation Targeting: Evidence of a Nonlinear Taylor Rule for the United Kingdom. Studies in Nonlinear Dynamics \& Econometrics, 10(4), - .

Vilademir, K. (2006). The inflation aversion of the Bundesbank: A state space approach. Journal of Economic Dynamics \& Control, 30, 1671-1686.

Yapraklı, S. (2011). Türkiye'de Açık Ekonomi Para Politikası Kuralının Geçerliliği: Sınır Testi Yaklaşımı. İs, Güç" Endüstri Ilişkileri ve Insan Kaynakları Dergis, 13(1), 127-142.

Yay, G. (2006). Para Politikası Stratejileri ve Enflasyon Hedeflemesi. Iktisat Dergisi(470-471), 3-17.

Yazgan, M., \& Yılmazkuday, H. (2004). Monetary Policy Rules in Practice: Evidence from Turkey and Israel. Applied Financial Economics, 17(1), 1-14.

Zheng, T., Wang, X., \& Guo, H. (2012). Estimating forward-looking rules for China's Monetary Policy: A regime-switching perspective. China Economic Review, 23, 47-59. 
